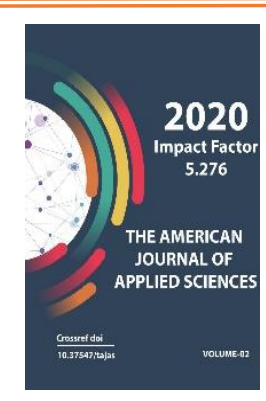

Copyright: Original content from this work may be used under the terms of the creative commons attributes 4.0 licence.

\section{Determination Of Thermal Parameters Of Solar Water Heating Collectors Using The "Dark" Testing Method}

\author{
Nizomjon Orifovich Usmonov \\ PhD, Associate Professor, Department Of “Thermodynamics And Heat Engineering", Tashkent \\ State Technical University, Uzbekistan \\ Xayrulla Sunnatullaevich Isakhojaev \\ PhD, Associate Professor, Department Of “Thermodynamics And Heat Engineering”, \\ Tashkent State Technical University, Uzbekistan \\ Saodat Rakhsulaevna Akhmatova \\ Senior Lecturer, Department Of “Thermodynamics And Heat Engineering”, Tashkent State \\ Technical University, Uzbekistan \\ Feruza Abdullaevna Khoshimova \\ Senior Lecturer, Department Of “Thermodynamics And Heat Engineering”, Tashkent State \\ Technical University, Uzbekistan
}

\title{
ABSTRACT
}

In the production of flat solar water heating collectors, thermal testing occupies a special place, the purpose of which is to determine their thermal characteristics experimentally. The corresponding approximation expressions are proposed for determining the coefficient of heat loss, inclined to the horizon at an angle of 300 for the average conditions of their operation in the hot water supply system.

\section{KEYWORDS}

Flat solar collector, radiant heat exchange panel, hot water supply system.

\section{INTRODUCTION}

Currently, serial production of flat solar water heating collectors (SWHC) is organized in many countries around the world. The organization of medium production of SWHC and the expansion of the scale of their use in hot water supply systems (HWSS) of objects for various purposes in the Republic of
Uzbekistan sets the task of their certification and certification, the solution of which includes the development of a whole system of tests (tests) aimed at determining their thermal efficiency, reliability and manufacturing quality control. A special place in it is occupied by thermal testing, the 
purpose of which is to determine their thermal characteristics experimentally.

\section{THE MAIN FINDINGS AND RESULTS}

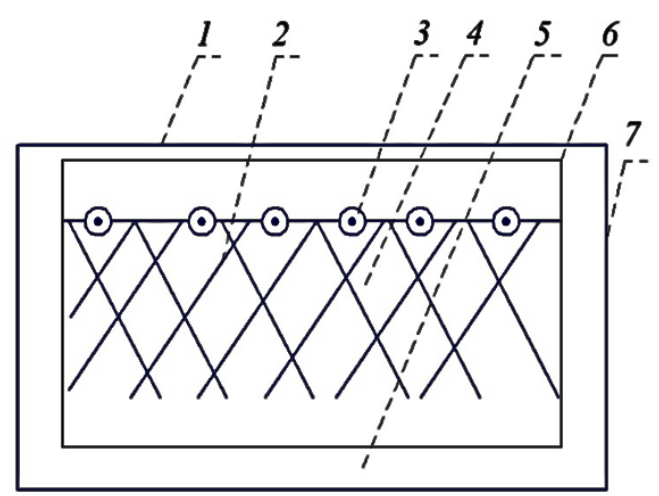

Fig.1-a
Typical SWHC consist of a blackened radiation absorbing heat exchange panel (BRAP) with built-in heat transfer channels (HRC), laid in a shallow flat box (body), with a translucent cover (TC), a thermally insulated bottom and side walls (Fig. 1-a).

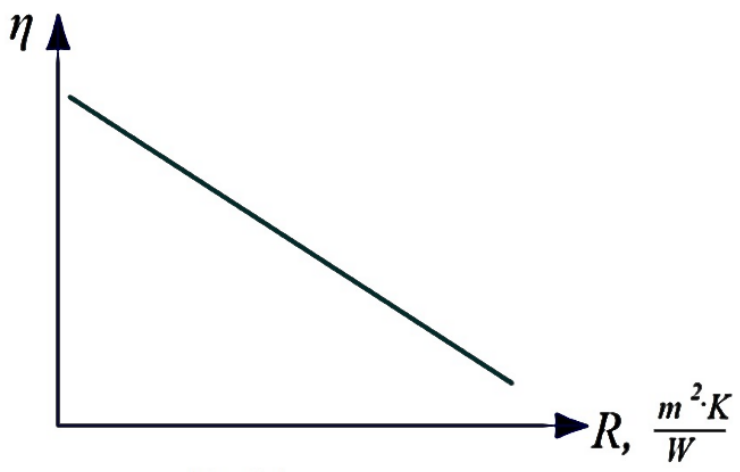

Fig. $1-b$

Figure: 1-a. Schematic diagram of the cross-section of the SWHC with sheet-tube BRAP: 1 - TC; 2 - blackened BRAP; 3 - HRC; 4 - bottom insulation; 5 - from the bottom of the wall; 6 - tank walls; 7 - case. Figure: 1-b. Addiction $\eta=f\left(\frac{t_{b}-t_{0}}{q_{\text {падс }}^{\Sigma}}\right)$.

In the blackened BRAP, the energy of solar radiation (SR) is absorbed and converted into heat, which has passed through the TC of the SWHC building. The TC, passing short-wave SR through itself, practically transmits back the long-wave (thermal) radiation of the blackened surface of the BRAP and, thereby, creates a greenhouse effect, excludes through radiant losses from the front surface of BRAP. The thermally insulated bottom and side walls of the housing reduce the conductiveconvective heat losses of the BRAP into the environment. Useful energy in the form of hot water with a temperature of $55-65^{\circ}$ is discharged through the built-in HRC in BRAP [1].

The results of thermal testing of SWHC are necessary for designers and manufacturers to work on their further improvement, and for suppliers and consumers to determine their nomenclature, compare them with each other and select a design that is most suitable for specific purposes.
The main indicators of the degree of thermal engineering quality of SWHC directly affecting their useful heat output $\left(q_{\text {пол }}\right)$ and thermal efficiency $(\eta)$ are reduced to a unit area of the frontal (front) surface of their body. The coefficient of total heat losses to the environment $\left(\mathrm{K}_{\mathrm{nр}} \mathrm{p}-0\right)$ and the coefficient of thermal efficiency of the BRAP of the considered SWHC $\left(\eta_{\text {тп }}\right)$, characterizing the efficiency of heat transfer from the elements of the BRAP to the water circulating inside the $\operatorname{HRC}\left(\eta_{\mathrm{T \Pi}}\right)$ and reduced to a unit area of the front surface of the collector body, the effective absorption capacity of the total SR, which characterizes the optical efficiency of the system "TC-BRAP" of the collector $\left(\eta_{0}\right)$ under consideration, which is determined by the product of the effective integral absorption capacity of the total SR of the blackened surface of BRAP $\left(\alpha_{\text {pэфф }}\right)$ by the effective throughput of the total SR TC $\left(\tau_{\text {сп эфф }}\right)$ reduced to a unit area of the front surface of the collector body, $\eta_{0}=$ $\left(\alpha_{\mathrm{p}} \tau_{\text {сп }}\right)_{\text {эфф} \cdot \cdot}$ 
To determine the values of these indicators of SWHC, a wide range of different methods of thermal testing has been proposed to date: full-scale, laboratory, quasi-stationary, nonstationary [1].

The basis of the ASHRAE SWHC quasistationary thermal testing method is a thermal model of the Hottel-Wheeler-Bliss collector with zero heat capacity, in which the influence of transient processes during heating (in the afternoon hours) of the collector on its thermal performance is neglected. In order to ensure the conditions of quasi-stationarity, thermal testing of the collector is carried out in the midday hours of clear days with the values of the surface flux density of the total (direct and diffuse) SR falling on the surface of $\mathrm{TC}\left(q_{\text {пад }}^{\Sigma}\right)$ not less than $630 \frac{\mathrm{BT}}{\mathrm{M}^{2}}$ and the angle of incidence of direct SR on the surface of TC $\left(i_{\text {пр }}\right)$ not more than 300 [2].

In the process of thermal testing of the SWHC, the flow rate of water through the collector $G_{\text {в }}\left(\frac{\kappa г}{\text { с }}\right)$, the temperature of water at the entrance to the collector $t_{\mathrm{B}_{\mathrm{BX}}}\left({ }^{\circ} \mathrm{C}\right)$ and at the outlet of it $t_{\mathrm{B}_{\mathrm{BX}}}\left({ }^{\circ} \mathrm{C}\right)$, the temperature of the outside air $t_{0}\left({ }^{\circ} \mathrm{C}\right)$, and the surface flux density of the total SR falling on the surface plane of the translucent cover of the collector $q_{\text {пад }}^{\Sigma}\left(\frac{\mathrm{BT}}{\mathrm{M}^{2}}\right)$ are measured.

The instantaneous values of the specific heat output $q_{\text {пол }}\left(\frac{\mathrm{BT}}{\mathrm{M}^{2}}\right)$ and thermal efficiency $(\eta)$ of the tested collector are determined from expressions

$$
\begin{aligned}
& q_{\text {пол }}=\left(m C_{\mathrm{p}_{\mathrm{B}}}\right)\left(t_{\mathrm{B}_{\text {вых }}}-t_{\mathrm{B}_{\mathrm{Bx}}}\right) \\
& \text { and } \\
& \eta=\frac{\left(m \mathrm{C}_{\mathrm{pв}}\right)}{q_{\text {падс }}^{\Sigma}}\left(t_{\mathrm{B}_{\text {вых }}}-t_{\mathrm{B}}\right), \\
& \text { where }
\end{aligned}
$$

$$
m_{\mathrm{B}}=\frac{G_{\mathrm{B}}}{F_{\phi \mathrm{p}}}
$$

$m_{\mathrm{B}}$ - is the specific water consumption through the collector with the frontal surface area of the body $F_{\phi \mathrm{p}}, C_{\mathrm{p}_{\mathrm{B}}}$ - is the specific heat capacity of water, $C_{\mathrm{p}_{\mathrm{B}}}=4186,8$ Дж/(кГ $\left.{ }^{\circ} \mathrm{C}\right)$.

The experimental results are processed in the form of dependence

$$
\eta=f\left(\frac{t_{\mathrm{B}}-t_{0}}{q_{\text {падс }}^{\Sigma}}\right) .
$$

The least regression method uses expression

$$
\eta=\eta_{m}\left[\left(\alpha_{\mathrm{p}} \tau_{\text {сп }}\right)-\frac{\kappa_{\text {пр }-0}}{q_{\text {пад }}^{\Sigma}}\left(t_{\mathrm{B}}-t_{0}\right)\right],
$$

proposed in the Hottel-Wheeler-Bliss model [1].

In (4) and (5) $t_{\mathrm{B}}$-, the temperature of the heated water averaged over the length of the heat-removing channel of the radiationabsorbing heat-exchange panel.

Note that for the developers and designers of solar water heating collectors, the values $\eta_{\text {тп }}$ and $\mathrm{K}_{\text {прро }}$, separately, are very important, and not $\eta_{\text {тп }} K_{\text {прро }}$ and $\eta_{\text {тп }}\left(\alpha_{\mathrm{p}} \tau_{\text {сп }}\right)_{э \phi \phi}$. Due to the fact that the values of complexes $\eta_{\text {тп }}$ and $\mathrm{K}_{\text {арро }}$ and $\quad \eta_{\text {тп }}\left(\alpha_{\mathrm{p}} \tau_{\text {сп }}\right)_{\text {эфф }}$ were obtained at around noon, they can only be used for comparison with similar indicators of flat solar water heating collectors of various manufacturers. For this reason, these 
complexes can be used to determine the daily variation of the heat output of the tested collectors, as suggested in [3].

From the graph of dependence $\eta=f\left(\frac{t_{b}-t_{0}}{q_{\text {падс }}^{\Sigma}}\right)$ in Fig. 1-b. the value of the sets, which are works, is determined $\eta_{\mathrm{T \Pi}} \mathrm{K}_{\text {пр }}$ and $\eta_{\text {тп }}\left(\alpha_{\mathrm{p}} \tau_{\text {сп }}\right)_{э \phi \phi}$.

As follows from the graph in Fig. 1-b., The ordinate of the intersection point of the straight line with the ordinate axis, i.e. at $\frac{t_{\mathrm{B}}-t_{0}}{q_{\text {пад }}^{\Sigma}}=0$, is equal to the value of complex $\eta_{\text {тп }}\left(\alpha_{\mathrm{p}} \tau_{\text {сп }}\right)_{э ф \phi}$, and the value of complex $\eta_{m} \cdot \mathrm{K}_{\text {пр р-0 }}$ is equal to the negative value of the slope of the straight line [3].

By including "dark" experiments in the program of their tests, it is possible to significantly reduce the duration of the thermal testing of SWHC and significantly reduce the labor intensity $[4,5,6]$.

$$
Q_{\text {тп }}=\left(G_{c p}\right)\left(t_{\mathrm{B}_{\mathrm{BX}}}-t_{\mathrm{B}_{\text {вых }}}\right)
$$

and lost into the environment through the enclosing elements of the SWHC

$$
Q_{\text {тп }}=\mathrm{K}_{\text {пр }-0} F_{\phi \mathrm{p}}\left(t_{\mathrm{B}}-t_{0}\right),
$$

i.e.

$$
\mathrm{K}_{\text {пр } \mathrm{p} 0}=\left(m c_{\mathrm{p}}\right) \frac{t_{\mathrm{B}_{\mathrm{BX}}}-t_{\mathrm{B}_{\mathrm{Bbx}}}}{t_{b}-t_{0}} .
$$

case.

The value $t_{b}$ in (7) and (8) can be determined from the expression

i.e. as a half-sum of $t_{b \mathrm{Bx}}$ and $t_{b \mathrm{Bdx}}$ or from expression

$$
t_{\mathrm{B}}=0,5\left(t_{\mathrm{B}_{\mathrm{BX}}}+t_{\mathrm{B}_{\mathrm{BbX}}}\right),
$$

$$
t_{\mathrm{B}}=t_{0}+\frac{t_{\mathrm{BX}_{\mathrm{BX}}}+t_{\mathrm{B}}}{\log _{t_{\mathrm{BBX}}-t_{0}}},
$$

Proposed in [2].

The value $\eta_{\text {тп }}$ according to [3] can be determined from the ratio

$$
\eta_{\text {тп }}=\frac{\kappa_{п p_{\mathrm{B}}-0}}{\mathrm{~K}_{\text {пр } \mathrm{p}-0}}
$$

The value $K_{п р}$ in this case can be determined from the approximation dependences

$$
\begin{aligned}
& \mathrm{K}_{\text {пр }-0}=2,3980+0,0044 t_{\mathrm{p}}-0,0121 t_{0}-1,1645 \varphi_{0}+4,2025 \varepsilon_{p}+0,0512 v+(182,9315- \\
& \left.5095,8649 \delta_{\text {впрс }}\right) \delta_{\text {впрс }}\left(\frac{\mathrm{Bт}}{\mathrm{M}^{2} K}\right) \cdot(12)
\end{aligned}
$$


in the range of $\varepsilon_{\mathrm{p}}$ from 0.10 to 0.25 and

$$
\begin{aligned}
& \mathrm{K}_{\mathrm{ap}_{\mathrm{p}-0}}=4,7838+0,0119 t_{p}-0,0193 t_{0}-1,6475 \varphi_{0}+2,4879 \varepsilon_{p}+0,1554 \vartheta+(82,6677- \\
& 2054,3139 \delta_{B} \text { тр } \delta_{B} \text { тр,(Втм2K), (13) }
\end{aligned}
$$

in the range of change $\varepsilon_{\mathrm{p}}$ from 0.80 to 0.9 , obtained on the basis of [5] with the corresponding heat loss coefficients of BRAP through the bottom and side walls of the SWHC $\left(1,5925 \frac{\mathrm{BT}}{\mathrm{M}^{2} K}\right)$ body and the ratio of the areas of the front surfaces of the $T C\left(F_{c n}\right)$ and the collector body $\left(F_{\phi p}\right)$, i.e.

$$
\frac{F_{\mathrm{cп}}}{F_{\phi \mathrm{p}}}=0,93 .
$$

In approximation expressions (12) and (13) $t_{\mathrm{p}}$ is the average operating temperature of BRAP; $\quad t_{0}$ and $\varphi_{0}-$, respectively, the temperature and relative humidity of the outside air; $\varepsilon_{\mathrm{p}}$ emissivity of the blackened surface of BRAP ; $\vartheta$ - wind speed, $\frac{\mathrm{M}}{\mathrm{c}} ; \delta_{\text {впр-с- }}$ the thickness of the closed air gap enclosed between the outer surface of the BRAP and the inner surface of the joint venture TC $\left(c_{1}\right)$.

Expressions (12) and (13) obtained for the average operating conditions of the SWHC in the HWSS and the angle of inclination of the SWHC to the horizon $(\alpha) 30^{\circ}$.

\section{CONCLUSIONS}

1. In this work, the technique of the "dark" method for determining the main heat engineering characteristics of SWHC used in HWSS is developed. As a result of heat losses of BRAP through the enclosing elements of the collector body into the environment, the water temperature at the outlet from it decreases to 11.

2. By including "dark" experiments in the program of their tests, it is possible to significantly reduce the duration of the process of thermal testing of SWHC and significantly reduce the labor intensity.

3. Approximation expressions are proposed for determining the reduced coefficient of heat loss of BRAP collector 12 inclined to the horizon at an angle of 300 for the average conditions of their operation in the HWSS.

\section{REFERENCES}

1. Beckman W., Klein S., Duffy D.J. Calculation of solar heating systems. Moscow. Energoizdat. 1982. - p. 80.

2. Avezov R.R., Avezova N.R. Development of a "dark" method for determining heat engineering collectors for heating a heat transfer fluid. Proceedings of the International Conference "Fundamental and Applied Problems of Physics" November 5-6, 2015. - pp. 343-345.

3. Avezov R.R., Vokhidov A.U., Usmonov N.O. Heat Transfer Coefficient from the Sheet-Piped Light-Absorbing Panels of the Flat-Plate Solar Water-Heating Collectors to the Heat Transfer Fluid in Their Heat-Removing Channels // Applied solar energy, 2018. №54. - pp. 168-172.

4. Usmonov N.O., Khazratov A.G. Influence of an internal heat source on the temperature field and heat transfer through the translucent coating of flat solar installations. Collection of articles based on the materials of the XLIX international scientific-practical conference "Experimental and theoretical research in modern science" 2020. - №1 (44) - pp. 70-76.

5. Usmonov N.O., Umarjanova F.Sh., Khashimova F.A. Flat solar water heating collectors are sources of thermal energy. 
Collection of articles based on the materials of the LVIII International Scientific and Practical Conference "Experimental and Theoretical Research in Modern Science" November 2020. - No. 10 (52) - pp. 54-58.

6. Usmonov N.O., Isaxodjayev X.S. Influence of the internal heat source on the temperature field and transfer through light-translucent coating of flat solar plants // The American journal of engineering and technology. 30 july, 2020. Volume-II, Issue-VII. - 46-50 p. doi: 10.37547/tajet/volume02issue07-07 